\title{
ADDENDUM
}

\section{Mechanochemistry: Tearing apart triazoles}

Stuart Cantrill

Nature Chemistry 3, 834-835 (2011); published online 24 October 2011; corrected after print 25 March 2015.

The Science article on which this Research Highlight is based was retracted (Editorial retraction. Science 347, 834; 2015) on 20 February 2015 after an investigation at The University of Texas at Austin found that the data and conclusions reported in the study are unreliable. 